\title{
THE CORRELATION BETWEEN FAMILY SUPPORT AND PREVENTION OF FAMILY NEGLECT IN FAMILY
}

1| Ezalina , 2| Rizanda Machmud, 3| Nursyirwan Effendi, 4| Yantri Maputra

Email : ezalin44@gmail.com

ABSTRAK

The neglect of the elderly is a failure in providing services in terms of fulfilling their physical, psychological, and financial needs that gives negative impacts on their health. With their family support, the health of the elderly can improve so that they can enjoy life in their old age.This study aims to identify the correlation between family support and the neglect of the elderly in their family in Pekanbaru City. This studyused descriptive correlation method to 382 elderly through direct interviews. The research instrument used was a questionnaire. The data were analyzed using univariate analysis through frequency distribution and bivariate analysisusing chi square test.The results showed a high neglect of $49.74 \%$ and a low neglect of 50.26\%.The type of neglect experienced by the elderly was psychological neglect namely high 59.68\% and low 40.32\%.The high support received by the elderly was 54,97\% and the low support was $45.03 \%$. The results of the correlation test analysis showed that there was a positive correlation between family support and neglect of the elderly with a $p$ value of 0,000 (OR $=2.02)$. The results of the study conclude that the higher the support given by the family to the elderly, the lower the neglect experienced by the elderly.
ARTICLE INFO

Keywords:

Neglect; Eelderly people;

Family support

DOI:

10.24252/kesehatan.v13i2

\section{Pendahuluan}

Sampai pertengahan tahun 2019 jumlah penduduk lansia mencapai 25,5 juta jiwa atau lebih dari 9\% dari total penduduk. Terjadinya transisi demografi berdampak pada bonus demografi akibat dari meningkatnya umur harapan hidup yaitu mencapai 71,39. Dampaknya Indonesia mengalami population ageing dan diperkirakan pada tahun 2045 tepat 100 tahun setelah Indonesia merdeka dimana lansia yang berusia 60 tahun keatas akan mencapai jumlah 19\% dari total penduduk(1).

Adanya proses menua menimbulkan berbagai masalah pada lansia baik fisik, biologis, mental, maupun sosial ekonomi. Hal ini mengakibatkan timbulnya gangguan dalam memenuhi kebutuhan hidup sehari-hari yang berakibat lansia bergantung pada orang lain yaitu keluarga. Angka beban ketergantungan menggambarkan beban ekonomi yang harus ditanggung penduduk usia produktif dalam menanggung biaya hidup lansia (2). Ketidakmampuan lansia dalam memenuhi kebutuhan dan akibat kelemahan fisik sehingga lansia rentan mengalami perilaku pengabaian oleh keluarga sebagai care giver(3).

Pengabaian lansia adalah suatu kegagalan dalam memberikan pelayanan dalam hal pemenuhan kebutuhan fisik, psikologis, dan finansial yang memberi dampak buruk pada kesehatan lansia. Kebutuhan tersebut seperti kebutuhan makan, tempat tinggal yang memadai, perawatan medis, dan keuangan. Angka kejadian pengabaian lansia yang dilaporkan oleh National Center on Elder Abuse yaitu 1 dari 10 lansia yang berusia lebih dari 60 tahun di Amerika mengalami pengabaian. Dari 5 juta lansia yang mengalami pengabaian di Amerika didapatkan 90\% pelaku adalah keluarga (4). Penelitian oleh McDonald (5) terhadap 267 lansia di Kanada didapatkan 24,4\% mengalami pengabaian sejak usia 55 tahun. Penelitian oleh Bigala \& Agiya (6) pengabaian dan kekerasan pada lansia merupakan masalah kesehatan serius yang dialami lansia.

Data dari Badan Pusat Statistik (BPS) didapatkan lansia terlantar pada tahun 2012 yaitu sebesar 13,7\% dan pada tahun 2014 meningkat menjadi 15\% (7). Penelitian oleh Steinmentz tentang penganiayaan dan pengabaian lansia di keluarga yang dilakukan oleh anak didapatkan pengabaian psikologis yaitu 30\% anak bicara kasar, 8,5\% mengancam untuk mengirim ke panti; pengababaian fisik yaitu $17 \%$ tidak memberikan makan dan pengobatan kepada lansia (3). Penelitian yang dilakukan oleh Sijuwade didapatkan pengabaian fisik yaitu 48\% keluarga tidak membawa lansia ke pelayanan kesehatan, 24\% keluarga tidak menolong lansia ketika mengeluhkan rasa letih, dan pengabaian finansial didapatkan $20 \%$ keluarga tidak pernah

\footnotetext{
${ }^{1}$ Program Studi S1 Keperawatan, Stikes Payung Negeri Pekanbaru Indonesia

${ }^{2}$ Fakultas Kedokteran Universitas Andalas Padang Indonesia

${ }^{3}$ Fakultas Ilmu Sosial Dan Ilmu Politik Universitas andalas Padang Indonesia

${ }^{4}$ Fakultas Kedokteran Psikologi Universitas Andalas Padang Indonesia
} 
menganggap serius soal keuangan yang dikeluhkan lansia. Perilaku pengabaian pada lansia dipicu oleh keterbatasan lansia dalam memenuhi kebutuhan hidup sehari-hari sehingga lansia harus tinggal dengan orang terdekat yaitu keluarga (8).

Keluarga adalah orang yang paling dekat dengan anggota-anggotanya yang dapat menimbulkan, mencegah, memelihara, dan mengabaikan masalah yang ada pada anggotanya. Adanya kehilangan otonomi dan fungsi membuat lansia sulit untuk melakukan kegiatan yang sederhana sehingga membutuhkan dukungan dari orang sekitar terutama keluarga (9). Keluarga yang merawat lansia dapat memberikan dukungan dengan cara memberikan pengakuan dan penghargaan atas setiap tindakan yang dilakukan lansia dan senantiasa lebih dekat melalui komunikasi yang dilakukan, memenuhi kebutuhannya, dan memberikan semangat agar menikmati kehidupannya dalam beraktifita(10).

Berdasarkan pilot studi yang peneliti lakukan di Puskesmas Harapan Raya Kecamatan Bukit Raya Kota Pekanbaru didapatkan 60\% lansia berusia mulai dari 60 tahun keatas, $63 \%$ berjenis kelamin perempuan, 63\% lansia tidak bekerja, 50,7\% lansia tinggal bersama anak. Ditinjau dari pengabaian yang dialami lansia didapatkan pengabaian fisik $39,2 \%$, pengabaian psikologis $45,8 \%$, dan pengabaian fianasial $29,5 \%$. Tujuan penelitian adalah untuk mengidentifikasi hubungan dukungan keluarga dengan pengabaian lansia pada keluarga di Kota Pekanbaru.

\section{Metode Penelitian}

Metode penelitian yang digunakan adalah deskriptif korelasi yaitu untuk mengetahui hubungan antara dua variabel melalui pendekatan crossectional(11). Variabel yang digunakan yaitu variabel bebas dukungan keluarga dan variabel terikat pengabaian lansia.

Populasi dalam penelitian ini adalah lansia yang berada di Kota Pekanbaru dimana jumlah lansia terbanyak berada di Kecamatan Payung Sekaki Kota Pekanbaru. Jumlah sampel sebanyak 382 orang yang berada di Kelurahan Labuh Baru Barat yang diambil dengan teknik multistage cluster sampling dengan kriteria lansia berusia mulai dari 60 tahun keatas, tinggal bersama anak atau terpisah dengan anak tapi masih dalam satu kota, dapat berkomunikasi secara efektif dan dapat mendengar. Alat pengumpulan data menggunakan kuesioner dimana data dikumpulkan melalui wawancara lansung kepada lansia.

Kuesioner dibuat sendiri oleh peneliti yang terdiri dari 3 bagian yaitu data karakteristik lansia, data dukungan keluarga dan data pengabaian lansia. Data dukungan keluarga terdiri dari dukungan informasi dengan alternatif jawaban menggunakan skala likert dengan jumlah 6 soal (rentang validitas 0,848-0,944 dengan reliabilitas 0,988), data dukungan penghargaan dengan jumlah 7 soal, (nilai validitas 0,727-0,966 dengan reliabilitas 0,998), data dukungan emosional dengan jumlah 6 soal (nilai validitas 0,851-0,920 dengan reliabilitas 0,964) dan data dukungan instrumental dengan jumlah 7 soal (rentang validitas 0,755-0,951 dengan reliabilitas 0,964). Untuk kuesioner pengabaian lansia dengan alternatif jawaban menggunakan skala likert, yang terdiri dari pengabaian fisik dengan jumlah 9 soal (rentang nilai validitas 0,588-0,910 dengan reliabilitas 0,936), pengabaian psikologis dengan jumlah 9 soal (rentang nilai validitas 0,6990,888 dengan reliabilitas 0,912) dan pengabaian fianansial dengan jumlah 6 soal (rentang nilai validitas 0,668-0,888 dengan reliabilitas 0,912). Dalam pengumpulan data peneliti dibantu oleh kader posyandu dan mahasiswa ners yang sebelumnya dilakukan persamaan persepsi atas pertanyaan yang ada dalam kuesioner.

Analisis data dilakukan dengan menggunakan program komputer melalui analisis univariat dan bivariat. Analisis univariat untuk mengetahui gambaran dari masing-masing variabel yang disajikan dalam bentuk distribusi frekwensi dan analisis bivariat mengguanakan uji chi squre untuk mengetahui hubungan antara variabel dukungan keluarga dan variabel pengabaian lansia. Penelitian dilakukan setelah mendapat persetujuan lolos kaji etik (ethical clearance) dari Universitas Riau dengan Nomor: 150/UN.19.5.1.1.8/UEPKK/2018 


\section{Hasil Penelitian}

Tabel 1 menjelaskan tentang karakteristik lansia, dari hasil didapatkan sebagian besar berusia 60-69 tahun sebanyak 194 orang (50,8\%), lebih dari separuh lansia berjenis kelamin perempuan yaitu 285 orang $(74,1 \%)$, sebagian besar lansia berpendidikan SD sebanyak 212 orang (55,5\%), lebih dari separuh lansia tidak bekerja yaitu sebesar 294 orang $(77,0 \%)$, lebih dari separuh lansia dengan penghasilan dibawah UMR (Rp. 2.550.000/bulan) yaitu sebanyak 286 orang $(74,8 \%)$, sebagian besar lansia mempunyai suku melayu yaitu 197 orang $(51,6 \%)$, lebih dari separuh lansia tinggal bersama anak yaitu 296 orang $(77,5 \%)$, lebih dari separuh lansia mempunyai asuransi kesehatan yaitu sebanyak 255 orang (66,8\%), dan sebagian besar lansia berstatus janda/duda sebanyak 263 orang (68,8\%).

Tabel 2 menunjukkan kejadian pengabaian lansia dalam keluarga. Berdasarkan jenis pengabaian yang dialami lansia didapatkan pengabaian psikologis paling banyak dialami lansia yaitu 228 orang $(59,68 \%)$, lalu diikuti oleh pengabaian finansial sebanyak 223 orang $(58,37 \%)$ dan pengabaian fisik sebanyak 122 orang $(31,94 \%)$.

Untuk melihat bentuk pengabaian yang dialami lansia berdasarkan jenis pengabaian yang dilakukan maka peneliti juga melakukan analisis kuesioner. Analisis kuesioner diolah berdasarkan jawaban yang nilai skalanya paling rendah tetapi paling banyak dijawab oleh lansia, baik soal favorable maupun unfavorable. Hal ini dapat dilihat pada tabel 3.

Tabel 4 menunjukkan bentuk dukungan keluarga ke lansia didapatkan dukungan tinggi sebanyak 210 orang $(54,97 \%)$ dan dukungan rendah sebanyak 172 orang (45.03\%). Berdasarkan analisis kuesioner tentang dukungan keluarga ke lansia dapat dilihat pada tabel 5. Pada tabel 5 menunjukkan bentuk dukungan keluarga ke lansia berdasarkan analisis kuesioner ditinjau dari dukungan informasi, dukungan dukungan penghargaan,dukungan emosional, dan dukungan instrumental.

Berdasarkan analisis bivariat dengan menggunakan uji chi square pada tabel 6 didapatkan hasil uji statistik nilai $p=0,00$ maka dapat disimpulkan terdapat hubungan yang signifikan antara dukungan keluarga dengan kejadian pengabaian lansia. Dari hasil analisis diperoleh pula nilai $\mathrm{OR}=2,02$ artinya dukungan keluarga yang tinggi kepada lansia mempunyai peluang 2 kali untuk lansia tidak terabaikan dibandingkan dukungan keluarga yang rendah.

Tabel 1. Distribusi Frekwensi Karakteristik Lansia di Kelurahan Labuh Baru Barat Kecamatan Payung Sekaki Pekanbaru $(n=382)$

\begin{tabular}{lccc}
\hline Variabel & Karakteristik & $\begin{array}{c}\text { Jumlah } \\
\text { (n=382) }\end{array}$ & Persentase (\%) \\
\hline Usia (tahun) & $60-69$ & 194 & 50,8 \\
& $70-79$ & 127 & 33,2 \\
& $\geq 80$ & 61 & 16,0 \\
\hline Jenis Kelamin & Prempuan & 283 & 74,1 \\
& Laki-laki & 99 & 25.9 \\
\hline Pendidikan & SD & 212 & 55,5 \\
& SMP & 142 & 37,2 \\
& SMA & 28 & 7,30 \\
\hline Pekerjaan & Bekerja & 86 & 23,0 \\
& Tidak bekerja & 296 & 77,0 \\
\hline Penghasilan & $<$ UMR & 286 & 74,8 \\
& $\geq$ UMR & 96 & 25,2 \\
\hline Suku & Melayu & 197 & 51,6 \\
& Jawa & 88 & 23,0 \\
& Minang & 57 & 14,9 \\
& Batak & 40 & 10,5 \\
\hline Tempat Tinggal & Bersama Anak & 296 & 77,5 \\
& Rumah Sendiri & 86 & 22,5 \\
\hline Kepemilikan Asuransi & Ya & 255 & 66,8
\end{tabular}


Tabel 2. Distribusi Frekwensi Kejadian Pengabaian Lansia Pada Keluarga di Kelurahan Labuh Baru Barat Kecamatan Payung Sekaki Pekanbaru $(n=382)$

\begin{tabular}{cccc}
\hline Nomor & Bentuk Pengabaian & Jumlah & Persentasi (\%)1 \\
\hline 1. & Fisik & 122 & 31,94 \\
\hline 2. & Psikologis & 228 & 59,68 \\
\hline 3. & Finansial & 223 & 58,37 \\
\hline & Jumlah & 384 & 100 \\
\hline
\end{tabular}

Tabel 3. Analisis Kuesioner Kejadian Pengabaian Lansia Dalam Keluarga Di Kelurahan Labuh Baru Barat Kecamatan Payung Sekaki Pekanbaru $(\mathrm{n}=382)$

\begin{tabular}{|c|c|c|}
\hline Variabel & & Persentase (\%) \\
\hline \multicolumn{3}{|l|}{ Pengabaian } \\
\hline - Tinggi & 190 & 49,74 \\
\hline - Rendah & 192 & 50,26 \\
\hline Total & 382 & 100 \\
\hline \multicolumn{3}{|l|}{ Pengabaian Fisik } \\
\hline - Tinggi & 122 & 31,94 \\
\hline - Rendah & 260 & 68.06 \\
\hline Total & 382 & 100 \\
\hline \multicolumn{3}{|l|}{ Indikator } \\
\hline $\begin{array}{l}\text { - Tidak mengindahkan penyakit yang dikeluhkan } \\
\text { lansia }\end{array}$ & 190 & 49,73 \\
\hline - Kebutuhan transportasi jarang dipenuhi keluarga & 282 & 73,82 \\
\hline $\begin{array}{l}\text { - Sering merasa lelah dengan pekerjaan rumah yang } \\
\text { dilakukan }\end{array}$ & 100 & 26,17 \\
\hline \multicolumn{3}{|l|}{ Pengabaian Psikologis } \\
\hline - Tinggi & 228 & 59,68 \\
\hline - Rendah & 154 & 40,32 \\
\hline Total & 382 & 100 \\
\hline \multicolumn{3}{|l|}{ Indikator } \\
\hline - Senantiasa tersinggung dengan ucapan anak & 352 & 92,14 \\
\hline - Merasa kesepian & 294 & 76,96 \\
\hline $\begin{array}{l}\text { - Nasehat yang disampaikan jarang diperhatikan oleh } \\
\text { anak. }\end{array}$ & 382 & 100 \\
\hline \multicolumn{3}{|l|}{ Pengabaian Finansial } \\
\hline - Tinggi & 223 & 58,37 \\
\hline - Rendah & 159 & 41,63 \\
\hline Total & 382 & 100 \\
\hline \multicolumn{3}{|l|}{ Indikator } \\
\hline $\begin{array}{l}\text { - Tidak menganggap serius soal keuangan yang } \\
\text { dikeluhakan lansia }\end{array}$ & 224 & 58,63 \\
\hline - Diminta menandatangani pengalihan kepemilikan & 30 & 7,85 \\
\hline - Jarang membantu biaya perawatan lansia ketika sakit & 154 & 40,31 \\
\hline
\end{tabular}

Tabel 4. Dukungan keluarga ke lansia Di Kelurahan Labuh Baru Barat Kecamatan Payung Sekaki Kota Pekanbaru (n=382)

\begin{tabular}{ccc}
\hline Katagori Dukungan & Frekuensi (f) & Jumlah (\%) \\
\hline Tinggi & 210 & 57,97 \\
Rendah & 172 & 45,03 \\
\hline
\end{tabular}


Tabel 5. Analisis Kuesioner Dukungan Keluarga Pada Lansia Di Kelurahan Labuh Baru Barat Kecamatan Payung Sekaki Pekanbaru (n=382)

\begin{tabular}{lcc}
\hline Dukungan Keluarga & Jumlah (n=382) & \% \\
\hline Dukungan Imformasi & & \\
- Tidak pernah mengingatkan lansia untuk mengecek & 280 & 73,29 \\
& & \\
kesehatan & 315 & 82,46 \\
- Jarang memantau obat yang di minum lansia & 273 & 71,46 \\
- Jarang mengingatkan lansia untuk melakukan senam & &
\end{tabular}

\section{Dukungan Penghargaan}

- Tidak pernah melibatkan lansia dalam mengambil

- Tidak pernah meminta lansia untuk menceritakan pengalaman hidup (life review)

- Tidak pernah memberikan kesempatan kepada lansia untuk melakukan aktifitas yang disenangi

\section{Dukungan emosional}

- Tidak pernah sabar dalam merawat lansia

- Tidak pernah merasakan apa yang dirasakan lansia

- Tidak pernah memberikan tempat tinggal yang nyaman bagi lansia

\section{Dukungan Instrumental}

- Tidak pernah menyediakan transportasi untuk

- Tidak pernah menyisihkan uang untuk pegangan 206 lansia

- Alat bantu yang dipakai sudah tidak layak lagi untuk digunakan (kaca mata kabur)

Tabel 6.Hubungan Dukungan Keluarga dengan Pengabaian Lansia Di Kelurahan Labuh Baru Barat Kecamatan Payung Sekaki Pekanbaru $(n=382)$

\begin{tabular}{|c|c|c|c|c|c|c|c|c|c|}
\hline \multirow{3}{*}{ Dukungan } & \multicolumn{4}{|c|}{ Abai } & \multirow{3}{*}{ Jumlah } & \multirow{3}{*}{$\%$} & \multirow{3}{*}{$p$} & \multirow{3}{*}{ OR } & \multirow{3}{*}{$\begin{array}{c}\text { CI } \\
(95 \%)\end{array}$} \\
\hline & & & & & & & & & \\
\hline & Tidak & $\%$ & Ya & $\%$ & & & & & \\
\hline Tinggi & 122 & 58,1 & 88 & 41,9 & 210 & 100 & 0,00 & 2,02 & $1,30-3,04$ \\
\hline Rendah & 70 & 40,7 & 102 & 59,3 & 172 & 100 & & & \\
\hline Jumlah & 192 & 50,3 & 190 & 49,7 & 382 & 100 & & & \\
\hline
\end{tabular}

\section{Diskusi}

Pengabaian adalah kegagalan keluarga dalam memberikan perawatan dan perlindungan, mengacuhkan, kurang empati, dan melalaikan pengasuhan kepada lansia baik dalam pemenuhan kebutuhan fisik, emosional, dan finansial. Pemenuhan kebutuhan lansia merupakan aspek yang tidak terpisah, jika keluarga tidak dapat memenuhi salah satu kebutuhan lansia maka keluarga sudah melalaikan tanggungjawab dalam memenuhi kebutuhan lansia. Jika perlakuan pemenuhan kebutuhan lansia dilakukan sekali-sekali maka orang tidak akan menganggap anggota keluarganya mengabaikan orang tua, karena dipandang sebagai hal yang tidak sengaja. Namun jika semua kebutuhan tidak terpenuhi dilakukan berulang kali dan dalam jangka waktu yang panjang, maka akan memunculkan kesan pengabaian. Hal ini kemudian menimbulkan pikiran bahwa anggota keluarga (care giver) tidak menghargai kebutuhan orang tua.

Hasil penelitian (12) tentang hubungan antara anak-anak dewasa, orang tua, dan kakek nenek semakin melemah hal ini karena terdapatnya kesenjangan antar generasi yang menyebabkan 
konflik dan ketegangan dalam keluarga yang membawa konsekuensi tidak sehat sehingga lansia yang sudah tidak lagi produktif menjadi terabaikan. Hampir semua lansia mengharapkan anak-anak mereka untuk merawat mereka saat sakit atau tidak bergerak dan takut jika dimasukkan dalam perawatan jangka panjang di rumah sakit atau panti jompo.

Dari tabel 1 terdapat lansia yang tdk tinggal bersama. Permasalahan yang dihadapi lansia yang tidak tinggal serumah dengan anak yaitu kesibukan dari anak-anak, tempat tinggal yang jauh sehingga anak jarang untuk mengunjungi, adanya konflik antara orang tua dengan anak dan anak tidak mau direpotkan dengan urusan orang tuanya serta orang tua sudah jarang dilibatkan dalam penyelesaian masalah. Hal ini menyebabkan lansia merasa tidak dibutuhkan lagi, tidak berguna, tidak dihargai dalam keluarga, dan merasa menjadi beban bagi keluarganya. Orang tua tidak peduli jika anak belum mampu memberi makan dengan baik, pakaian yang tepat, semua yang diinginkan orang tua adalah anak cinta kepada orang tua, dan ketika orang tua tinggal bersama, orang tua disambut oleh keluarga (13).

Dari tabel 3 hasil analisis kuesioner untuk pengabaian psikologis didapatkan lansia sering tersinggung dengan ucapan anak $(92,14 \%)$, merasa kesepian $(76,96 \%)$ dan nasehat yang disampaikan jarang dilaksanakan oleh anak. Hal ini sejalan dengan penelitian yang dilakukan oleh Khanal (14) bahwa 32\% lansia merasa kesepian dan 22\% merasa kehilangan anak-anak mereka meskipun mereka hidup dalam sistem keluarga bersama. Dari hasil wawancara yang peneliti lakukan kepada lansia ketika mengisi kuesioner didapatkan banyak keluarga yang sudah tidak mempunyai waktu untuk mendengarkan keluhan lansia dikarenakan minimnya interaksi sosial antara orang tua dan anggota keluarga. Apa yang dirasakan lansia kurang dipedulikan oleh keluarga sehingga lansia merasa diabaikan keluarga.Begitu pula untuk pengabaian finansial 58,63\% keluarga tidak menganggap serius soal keuangan yang dikeluhkan lansia. Lansia sangat senang jika diberikan uang oleh anak dan menawarkan bantuan uang saat butuh pengobatan.

Mendampingi dan merawat orang tua oleh keluarga merupakan sesuatu yang sulit dan rumit, tidak mudah, karena merupakan aktifitas yang terus menerus, dan biasanya dilakukan oleh satu orang saja (dekat dan serasi dengan lansia) dan membutuhkan kesabaran, cinta, tidak mementingkan diri sendiri. Begitu pula untuk lansia yang sudah mengalami penyakit kronis yang membutuhkan perawatan, bukanlah tugas yang mudah, dalam konteks ini akan ada kebutuhan sekunder pengasuh untuk bertukar shift dalam merawat lansia(Stanhope Lancaster, 2016). Dalam proses penuaan, beberapa perubahan fisiologis menjadi lebih terlihat sehingga mempengaruhi kapasitas fungsional lansia. Dalam pengertian ini ketergantungan, kehilangan otonomi dan fungsi membuat lansia sulit untuk melakukan kegiatan sehari-hari yang sederhana sehingga membutuhkan dukungan dari orang sekitar terutama keluarga (Floriano et al., 2012).

Berdasarkan analisis tabel 5 meskipun lansia mendapatkan dukungan instrumental dari keluarga tetapi terkadang lansia tidak memiliki semangat yang cukup untuk meningkatkan kepuasan hidup, karena kesejahteraan pada lansia dipengaruhi oleh beberapa faktor kepribadian seperti kompetensi pribadi dan sosial, jauh dari konflik dan stres. Dalam hal dukungan imformasi lansia suka membicarakan apapun dengan pasangan dan anak-anak mereka, bertukar imformasi, memberikan masukan sehingga keluarga bisa memahami dan memecahkan masalah lebih mudah. Untuk dukungan penghargaan dapat dilakukan keluarga melalui pemberikan rasa hormat, memotivasi ide-ide lansia, dan memuji apa yang telah lansia lakukan.

Dari tabel 6 didapatkan terdapat hubungan yang signifikan antara dukungan keluarga dengan pengabaian lansia. Hal ini sejalan dengan penelitian Floriano (9) yang menunjukkan ada hubungan yang signifikan antara dukungan keluarga dengan tingkat kemampuan activity of daily living (ADL) lansia. Hal ini sejalan dengan penelitian yang peneliti lakukan bahwa terdapat hubungan antara dukungan keluarga dengan perilaku pencegahan pengabaian lansia di keluarga dimana nilai OR didapatkan 2,02 yang artinya lansia yang mendapat dukungan keluarga yang rendah akan menyebabkan terjadinya pengabaian lansia sebesar 2,02 kali 
dibandingkan lansia yang mendapatkan dukungan keluarga tinggi. Keluarga yang merawat lansia di harapkan dapat meningkatkan dukungan kepada lansia dengan cara memberikan pengakuan dan penghargaan atas setiap tindakan yang dapat dilakukan lansia secara mandiri dan senantiasa lebih dekat kepada lansia, tetap berkomunikasi, memenuhi kebutuhannya, dan selalu memberi semangat untuk lansia agar lansia menikmati kehidupannya dalam beraktifitas sehari-hari.

Hasil penelitian Kaur (15) menunjukkan orang tua yang mendapatkan dukungan dari anggota keluarga (mean 90,78) memiliki kualitas hidup yang lebih baik dari pada mereka yang mendapatkan dukungan dari pasangan (mean 72,94) atau tidak mendapatkan dukungan apapun (mean 52,40) dengan pvalue 0,03. Hubungan keluarga dan dukungan sosial secara signifikan terkait dengan kualitas hidup lansia, dimana masalah penyesuaian terhadap kesehatan, ekonomi, dan sosial berdampak jangka panjang pada kwalitas hidup lansia, artinya lansia yang tidak memiliki masalah besar memiliki kwalitas hidup yang lebih baik karena orang tua yang sehat melakukan kegiatan sehari-hari secara mandiri.

\section{Kesimpulan}

Adanya hubungan yang positif antara dukungan keluarga dengan pengabaian lansia pada keluarga. Artinya semakin tinggi dukungan yang diberikan keluarga kepada lansia semakin rendah pengabaian yang dialami lansia pada keluarga.

\section{Daftar Pustaka}

1. Kemenkes. (2019). Analisis lansia di Indonesia. Pusat Data Dan Imformasi Kemenkes.

2. UNFPA. (2014). Monogfafh series No.1Indonesia on the threshold of population ageing. Jakarta: UNFPA Indonesia.

3. Friedman, M., BBoden, V., \& Jones, E. (2010). Family Nursing, research, theory and practice No Title. New Jersey: Prentice Hill.M. Mahjoob, J. Nejati, A. Hosseini, and N. M. Bakhshani, "The Effect of Holy Quran Voice on Mental Health," J. Relig. Health, vol. 55, no. 1, pp. 38-42, 2016.

4. National Center on Elder Abuse. (2017). Elder Abuse Research Review, September 2014August 2017. 163(AUGUST), 877-878. https://doi.org/10.2105/AJPH.2017.303821aP. Mendengarkan and A. Al Quran, "Fitriatun, dkk/ Pengaruh Mendengarkan Ayat-ayat Al Quran 1," pp. 1-17.

5. McDonald, L., \& Thomas, C. (2013). Elder abuse through a life course lens. International Psychogeriatrics, 25(8), 1235-1243.U. Rusli, "Inisiasi Menyusui Dini Plus Asi Ekslusif," IVEY business journal. 2012.

6. Bigala, P., \& Ayiga, N. (2014). Prevalence and predictors of elder abuse in mafikeng local municipality in South Africa. Etude de La Population Africaine, 28(1), 463-474. https://doi.org/10.11564/28-1-500

7. BPS. (2015). Statistik Penduduk Lanjut Usia. Badan Pusat Statistik.

8. Low, L. F., Yap, M., \& Brodaty, H. (2011). A systematic review of different models of home and community care services for older persons. BMC Health Services Research, 11(1), 93. https://doi.org/10.1186/1472-6963-11-93.

9. Floriano, L. A., Azevedo, R. C. de S., Reiners, A. A. O., \& Sudré, M. R. S. (2012). Cuidado Realizado Pelo Cuidador Familiar ao Idoso Dependente, em Domicílio, no Contexto da Estratégia de Saúde da Família. Texto e Contexto Enfermagem, 21(3), 543-548. https://doi.org/10.1590/S0104-07072012000300008.

10. Samjana, T. (2017). Abandonment of Elderly People in. 1-40.

11. Creswel, J. W. (2016). Research Design: pendekatan kualitatif, kuantitatif, dan campuran. Yogyakarta: Pustaka Pelajar. 
12. Alavi, K., Sail, R. M., Idris, K., Samah, A. A., \& Omar, M. (2011). Living arrangement preference and family relationship expectation of elderly parents. Pertanika Journal of Social Science and Humanities, 19(SPEC. ISSUE), 65-73.

13. Punyakaew, A., Lersilp, S., \& Putthinoi, S. (2019). Active ageing level and time use of elderly persons in a Thai suburban community. Occupational Therapy International, 2019. https://doi.org/10.1155/2019/7092695.

14. Khanal, P., Rai, S., \& Chalise, H. N. (2018). American Journal of Gerontology and Geriatrics Children 's Migration and Its Effect on Elderly People: A Study at Old Age Homes in Kathmandu. (June 2019).

15. Kaur, H., Kaur, H., \& Venkateashan, M. (2015). Factors determining family support and quality of life of elderly population. International Journal of Medical Science and Public Health, 4(8), 1049. https://doi.org/10.5455/ijmsph.2015.21012015220 